\title{
Mass mortality of pearl oyster (Pinctada fucata (Gould)) in Japan in 2019 and 2020 is caused by an unidentified infectious agent
}

\author{
Tomomasa Matsuyama ${ }^{\text {Corresp., } 1}$, Satoshi Miwa ${ }^{1}$, Tohru Mekata $^{1}$, Yuta Matsuura ${ }^{1}$, Tomokazu Takano ${ }^{1}$, Chihaya \\ Nakayasu ${ }^{1}$ \\ ${ }^{1}$ Fish pathology department, Aquaculture Research Department, National Research and Development Agency, Japan Fisheries Research and Education \\ Agency, Minami-Ise, Mie prefecture, Japan \\ Corresponding Author: Tomomasa Matsuyama \\ Email address: matsuym@fra.affrc.go.jp
}

Mass mortality of 0-year-old pearl oysters, Pinctada fucata (Gould), and anomalies in adults were observed in Japan's major pearl farming areas in the summer of 2019 and 2020. Although adult oyster mortality was low, both adult and juvenile oysters underwent atrophy of the soft body, detachment of the mantle from nacre (the shiny inner surface of the valves), deposition of brownish material on the nacre, and loss of nacre luster. Infection trials were conducted to verify the involvement of pathogens in this phenomenon. Healthy adult pearl oysters were obtained from areas where this disease had not occurred to use as the recipients. The sources of infection were either affected adult oysters with atrophied soft bodies or batches of juveniles in which mortality had reached conspicuous levels. Transmission of the disease to the healthy oysters were tested either by cohabitation with affected oysters or by injections of the hemolymph of affected animals. The injection infection test examined the effects of filtration and chloroform exposure on the pathogen. Occurrence of the disease was confirmed by the appearance of brown deposits on the nacre and loss of nacre luster. The abnormalities of nacre were clearly reproduced in recipient shells in 3 out of 4 cohabitation trials with affected oysters. The disease was also reproduced in 6 out of 6 injection trails either with hemolymph filtered through $100 \mathrm{~nm}$ filter or with hemolymph treated with chloroform. In a serial passage with hemolymph injections, the disease was successfully transmitted through 8 passages. These results suggest that the etiology of the disease is a nonenveloped virus with a diameter $\leq 100 \mathrm{~nm}$. 
1 Mass mortality of pearl oyster (Pinctada fucata (Gould)) in Japan in 2019 and 2020 is caused by

2 an unidentified infectious agent.

3

4

10 Corresponding Author:

11 Tomomasa Matsuyama,

12 Minami-Ise, Mie prefecture, 516-0108, Japan

13 Email address: matsuym@fra.affrc.go.jp

\section{Introduction}

\section{Abstract}

Mass mortality of 0-year-old pearl oysters, Pinctada fucata (Gould), and anomalies in adults were observed in Japan's major pearl farming areas in the summer of 2019 and 2020. Although adult oyster mortality was low, both adult and juvenile oysters underwent atrophy of the soft body, detachment of the mantle from nacre (the shiny inner surface of the valves), deposition of brownish material on the nacre, and loss of nacre luster. Infection trials were conducted to verify the involvement of pathogens in this phenomenon. Healthy adult pearl oysters were obtained from areas where this disease had not occurred to use as the recipients. The sources of infection were either affected adult oysters with atrophied soft bodies or batches of juveniles in which mortality had reached conspicuous levels. Transmission of the disease to the healthy oysters were tested either by cohabitation with affected oysters or by injections of the hemolymph of affected animals. The injection infection test examined the effects of filtration and chloroform exposure on the pathogen. Occurrence of the disease was confirmed by the appearance of brown deposits on the nacre and loss of nacre luster. The abnormalities of nacre were clearly reproduced in recipient shells in 3 out of 4 cohabitation trials with affected oysters. The disease was also reproduced in 6 out of 6 injection trails either with hemolymph filtered through $100 \mathrm{~nm}$ filter or with hemolymph treated with chloroform. In a serial passage with hemolymph injections, the disease was successfully transmitted through 8 passages. These results suggest that the etiology of the disease is a non-enveloped virus with a diameter $\leq 100 \mathrm{~nm}$.

The Akoya pearl oyster, Pinctada fucata (Gould), is the major species that is used for pearl culture in Japan In recent years, the annual production of pearls in Japan has been approximately 20 tons and the annual export value 
35 is approximately 30 billion yen, which is second only to scallops. More than $90 \%$ of Akoya pearls are produced in 36 Ehime, Nagasaki, and Mie prefectures (Fig. 1).

Mass mortalities of juvenile Akoya oysters and adult Akoya oysters with atrophy of the soft body were reported on pearl oyster farms in Mie Prefecture in June 2019 and Ehime Prefecture in early August 2019. Later in 2019, similar cases were reported from major pearl production areas, such as Nagasaki, Kumamoto, and Oita prefectures. In particular, the death of 0 -year-old oysters (hereinafter referred to as juveniles) was considerable. According to the inquiry conducted by the Mie Prefecture Fisheries Research Institute to multiple pearl farming companies in three regions of the prefecture, the mortalities of juveniles and adults were $56-74 \%$ and $23-24 \%$, respectively in 2019, whereas those in typical years were $15 \%$ and $9-16 \%$. In 2020, similar abnormalities occurred in all major pearl farming regions in the country, from June to November when the water temperature was high, attaining the peak in June or July.

To date, the major infectious diseases known to affect $P$. fucata oysters in Japan are Akoya oyster disease (Kurokawa et al., 1999, Matsuyama et al., 2017, 2018, 2019), black-spot shell disease (Sakatoku et al., 2018), marine birnavirus infection (Suzuki et al. 1998a, b), and trematode infestation (Sakaguchi et al., 1968). However, the mortality or abnormalities that occurred in 2019 and 2020 differ from any of these diseases and are referred to herein as "summer atrophy". In healthy pearl oysters, the outer edge of the mantle is in close contact with the edge of the nacre surface (Fig. 2D). In the oysters with summer atrophy, the mantle was detached from the nacre, and the entire soft body contracts toward the dorsal margin (Fig. 2A). Shell spines often developed in the infected group (Fig. 2C), and thus, the shell formation is probably normal until just before the disease onset. While the pearl oyster is sometimes atrophied due to low water temperatures in winter, no disease accompanied by atrophy during the period of high water temperatures has been reported until the occurrence of summer atrophy. Pearl oysters that have recovered from summer atrophy showed symptoms of so-called "shell disease" (Huang et al., 2019), which is characterized by brownish deposit on the nacre and loss of nacre luster often in the areas close to the edge of the nacre (Fig. 2A-C). It is speculated that the deposition of brownish substance occurs due to the formation of a prismatic layer on the surface of the nacre during the process of the exfoliated mantle returns to its original position (Sano et al., 2021). The prismatic layer is usually formed on the outer layer of the nacre. The loss of luster is probably the result of denaturation of the nacre by being exposed to seawater when the mantle is detached from the nacre surface. The abnormalities in the nacre were observed in $60-97 \%$ of the oysters that survived summer atrophy, according to a survey by the Mie Prefecture Fisheries Research Institute. Black-spot shell disease also causes aberrant pigmentation in the nacre, but the deposits are darker than those occurring with summer atrophy. Furthermore, deposition of black-spot shell disease typically occurs towards the dorsal edge (Fig. 2E), and death does not occur. Akoya oyster disease causes atrophy of the soft body, whereas the nacre remains normal (Fig. 2F), and mortality is high among adults (Iwanaga et al., 2008). Although mortality from marine birnavirus infection have been reported, the pathogenicity of the virus is relatively low (Suzuki et al., 1998b).

Environmental factors have been suspected of the cause of the disease, such as high water temperatures, decrease in food plankton, or chemical pollution. However, it is unlikely that these environmental changes caused summer atrophy, considering that the disease with the same symptoms occurred almost simultaneously in most of 
72 the pearl culture regions throughout Japan, where environmental conditions vary substantially. In addition, no

73 abnormalities have been reported in organisms other than pearl oysters, such as other shellfishes and fish, in the

74 areas where summer atrophy has been reported. On the other hand, the disease could be explained by an infectious

75 agent, which might have spread in the first year from the original outbreak through the active transportation of

76 juvenile oysters among culture areas, causing outbreaks almost simultaneously at a variety of locations across the

77 country in the second year. In this study, we conducted infection tests to verify whether summer atrophy is a

78 transmissible disease.

79

\section{Materials \& Methods}

\section{Animals}

Details and localities of the pearl oysters, Pinctada fucata (Gould), used in each infection test are shown in

Table 1 and Fig. 1. One-year-old, healthy pearl oysters were obtained from Ishikawa or Kanagawa Prefecture, where pearls are not cultivated (Fig. 1, Table 1). These oysters were used as recipients and negative control donors in the infection tests. The pearl oysters from Ishikawa Prefecture that were used as recipients in Test 2 showed slight pigmentation on the nacre in 2 of the 10 individuals observed, although the nature of pigmentation was much darker than those typically found in the oysters affected by summer atrophy and rather similar to that of black-spot shell disease. For the donors, shells exhibiting atrophy in the soft body were obtained from a pearl oyster farmer in Mie Prefecture (Table 1). Prior to the start of each experiment, 5 or 10 individuals were randomly sampled from each batch to examine atrophy of the soft body and nacre abnormality. Oysters of each experimental group were reared in the same $65-\mathrm{L}$ tank and different groups were separately reared in different $65-\mathrm{L}$ tanks. The tanks were filled with $56 \mathrm{~L}$ running seawater (approximately $250 \mathrm{~mL} / \mathrm{min}$ ) filtered with a $1-\mu \mathrm{m}$ pore size filter and maintained at $23-25^{\circ} \mathrm{C}$ under the natural photoperiod in the laboratory. For food, $500 \mathrm{~mL}$ of cultured diatoms (Chaetoceros neogracile, approximately $5 \times 10^{5}$ cells $/ \mathrm{mL}$ ), was added to each aquarium five times per week.

\section{Scoring degree of disease}

Although the infection tests were performed using 1-year-old adult oysters in this study, the mortality by summer atrophy of shells over 1-year-old is low. Consequently, severity of the disease in the infection tests could not be assessed by mortality. The atrophy of the soft body is characteristic of the disease. However, the atrophy occurs only transiently at different times in different individual oysters, and shells must be opened when the atrophy is most severe, to determine the severity of the disease. This is intrinsically difficult. On the other hand, observations of the valves of spontaneously diseased oysters suggest that the deposition of brown pigment and loss of nacre luster are also characteristic of this disease. These nacre abnormalities remain long after the oysters recover from the disease, so that the shells can be opened at any arbitrary timing to determine the severity of the disease. Therefore, in this study, the degree of disease severity was determined using abnormalities in the nacre. 
108

109

110

111

112

113

114

115

116

117

118

119

120

121

122

123

124

125

126

127

128

129

130

131

132

133

134

135

136

137

138

139

140

141

142

143

scores of oysters in one group was divided by the number of tested oysters in the group to obtain the mean shell score of the group. For the investigation of the nacre of farmed oysters that was affected by spontaneously occurring summer atrophy, the sum of the scores of valves for each group of oysters was divided by the number of observed valves to obtain the mean shell score of the group. This is because the two valves of a stored individual oyster had usually fallen apart and reconstruction of an individual by two valves was difficult.

\section{Investigation of spontaneously occurring disease in farmed oysters}

Atrophy of the soft body and abnormalities in the nacreous layer were investigated in cultured and wild pearl oysters. Cultured oysters were obtained from the areas where summer atrophy is occurring, and wild, disease-free oysters were from the areas where the disease has not been reported (Table 2). We also observed the nacreous layer of stored valves of cultured pearl oysters. These oysters had been collected in Mie prefecture before June 2019, prior to the first outbreak of summer atrophy.

\section{Test 1: Cohabitation and injection challenge using adult pearl oysters as the infection source}

In the cohabitation test, 5 diseased 3-year-old oysters and 14 healthy oysters were reared in different net cages set in a 65-L tank under the conditions described above so that the diseased and healthy oysters are not in contact with each other. For the negative control, 19 healthy oysters were reared similarly in another 60-L tank. In the injection test, the hemolymph of 15 diseased oysters was collected from the adductor muscles. The hemolymph was pooled and centrifuged at $1200 \times g$ for 10 min to obtain the supernatant, which was used as the inoculum. This inoculum was injected into the adductor muscles of 14 healthy pearl oysters $(100 \mu 1 /$ individual $)$ with $23 \times 1 / 4$ gauge needles. For the negative control, 14 healthy oysters were inoculated with hemolymph into the adductor muscles using supernatant prepared from 3 healthy oysters by the above method. Experiments were performed at two different water temperatures, $25^{\circ} \mathrm{C}$ and $22-23^{\circ} \mathrm{C}$. That is, a total of eight test groups were set (Table 2). The mortality was monitored during the experiment. Since the abnormality on the nacre seemed to take several days to appear and mortality sometimes occurred early in the experiments, the shell scores were determined only on surviving specimens 27 days after the start of each experiment.

\section{Test 2: Injection challenge using juvenile pearl oysters as the infection source}

Soft bodies were collected from 120 -year-old juveniles from an affected group. They were pooled $(0.41 \mathrm{~g}$ in total wet weight), chopped with scissors in $2 \mathrm{~mL}$ of autoclaved seawater, and centrifuged at $1200 \times \mathrm{g}$ for $10 \mathrm{~min}$ to obtain the supernatant as the inoculum. The inoculum for the negative control was prepared in the same way from healthy pearl oysters ( $0.43 \mathrm{~g}$ in total wet weight). Each inoculum was injected into the adductor muscles of 10 healthy oysters (100 $\mu \mathrm{l} /$ individual). The mortality was monitored, and the shell scores were determined on surviving individuals 18 days after the injections.

\section{Test 3: Filterability}


144

145

146

147

148

149

150

151

152

153

154

155

156

157

158

159

160

161

162

163

164

165

166

167

168

169

170

171

172

173

174

175

176

\section{7}

178

179

180

Soft bodies were collected from 20 diseased 0 -year-old juveniles, pooled ( $4.9 \mathrm{~g}$ in total wet weight), and cut into small pieces with scissors. The volume of the minced tissues was adjusted to $50 \mathrm{~mL}$ with autoclaved seawater and centrifuged at $1200 \times g$ for $10 \mathrm{~min}$ to obtain the supernatant. The supernatant was then sequentially filtered through $0.8 \mu \mathrm{m}, 0.45 \mu \mathrm{m}, 0.22 \mu \mathrm{m}$, and $0.1 \mu \mathrm{m}$ filters (Millipore, Millipore Co., Tokyo, Japan). Part of each filtrate was saved and inoculated to the adductor muscles of 7 healthy oysters (100 $\mu \mathrm{l} /$ individual). Thus, the total of 28 shells were used. For the positive control, diseased oysters $(\mathrm{N}=5)$ and healthy oysters $(\mathrm{N}=7)$ were reared in the same aquarium as in Test 1 , since it had been known that the disease could be transmitted through cohabitation by the time when this test was conducted. Two negative control groups were also prepared. For one group, only healthy pearl oysters $(\mathrm{N}=7)$ were reared in an aquarium. For the other, supernatant of the soft body $(4.86 \mathrm{~g})$ from a single healthy animal was prepared as described above and injected into the adductor muscles of 7 healthy oysters (100 $\mu 1 /$ individual) without filtration. Experiments were performed in duplicate in all test groups including positive and negative controls. The mortality was monitored, and the shell scores were determined on surviving individuals 38 days after the start of the experiment.

\section{Test 4: Serial passages}

To further clarify whether the disease was transmissible, we performed an experiment to know whether the disease could be passed on repeatedly. The serial passages were conducted with 3 different intervals: $1 \mathrm{~h}, 5$ days, and 10 days. The outline of the test is shown in Fig 4. Soft bodies collected from 100 -year-old oysters of an affected group were pooled (wet weight $4.0 \mathrm{~g}$ ) and cut into small pieces with scissors. The volume of the minced tissues was adjusted to $6 \mathrm{~mL}$ with autoclaved seawater and centrifuged at $1200 \times \mathrm{g}$ for $10 \mathrm{~min}$. The supernatant was filtered through a 0.1 um filter (Millipore). The filtrate was injected into the adductor muscles of 25 healthy oysters (100 $\mu 1 /$ individual); this infection test was defined as the first passage. From the 25 oysters, 5 individuals were randomly selected at 1 hour, 5 days, and 10 days after the inoculation, and the hemolymph was collected and pooled to prepare the inoculum for the second passage. The pooled hemolymph was centrifuged at $1200 \times g$ for $10 \mathrm{~min}$ to obtain the supernatant as the second inoculum. The inoculum was injected into the adductor muscles of 12 healthy pearl oysters ( $100 \mu \mathrm{l} /$ individual) in each test series (total $\mathrm{N}=36$ ). As for the third passage, 5 individuals were selected from each group at 1 hour, 5 days, and 10 days after the second inoculation, and the hemolymph was collected and used as the inoculum. This procedure was repeated up to the 3 rd passage for the 1 -hour interval passages, to the 4th passage for the 5-day interval passages, and to the 8th passage for the 10-day interval passages. The remaining oysters in each passage (10 individuals for the first passage and 7 for the other passages) were kept for 3 weeks to observe shell abnormality. For negative controls, 7 healthy oysters were similarly inoculated with supernatant of hemolymph that was prepared from 5 healthy animals. Serial passages were not conducted for the negative controls.

\section{Test 5: Chloroform sensitivity}

This test was performed twice (Table 1). As the inoculum in the first test (Test 5-1), the supernatant of the hemolymph used for the infection of the first passage in Test 4 was used. In the second test (Test 5-2), the supernatant of the hemolymph used for the third passage in the 10-day interval passages in Test 4 was used. In both 
181 tests, the inoculum was divided into two equal aliquots, an equivalent volume of chloroform was added to one

182

183

184

185

186

187

188

189

190

191

192

193

194

195

196

197

198

199

200

201

202

203

204

205

206

207

208

209

210

211

212

\section{Statistics}

214 The mean shell scores were expressed as means \pm standard error. The mortality and prevalence of nacre

215 abnormalities in survivors were analyzed statistically with Fisher's exact test, and the mean shell scores were tested 216 by Mann-Whitney U-test or the Steel-Dwass test. A value of $p<0.05$ was considered to be statistically significant. aliquot, and the mixture was shaken at $25^{\circ} \mathrm{C}$ at $300 \mathrm{rpm}$ for 10 minutes and then centrifuged at $1200 \times g$ for 10 minutes to recover the aqueous layer as the chloroform-treated inoculum. The other was similarly shaken and centrifuged without adding chloroform and used as the non-treated inoculum. For the negative control, supernatant of the hemolymph (centrifuged at $1200 \mathrm{x} \mathrm{g}$ for $10 \mathrm{~min}$ ) of a single healthy oyster was used as the inoculum. Each inoculum was injected into the adductor muscles of 5 and 7 healthy pearl oysters in the Tests 5-1 and 5-2, respectively (100 $\mu \mathrm{l} /$ individual). The mortality was monitored during the experiments. The shell scores were determined on the surviving individuals 15 and 20 days after the injections in the two tests, respectively.

\section{Test 6: Thermal stability}

This test was performed twice (Table 1). In the first test (Test 6-1), the supernatant of the hemolymph used for the 7th passage in the 10-day interval passages in Test 4 was used as the inoculum. In the second test (Test 6-2), the inoculum was prepared from 0-year-old juveniles of an affected group (Table 1); soft bodies were collected from 10 juveniles, pooled ( $0.8 \mathrm{~g}$ in total wet weight), chopped with scissors in $5 \mathrm{~mL}$ of autoclaved seawater, and centrifuged at $1200 \mathrm{x} g$ for $10 \mathrm{~min}$ to obtain the supernatant as the inoculum. For each experiment, the inoculum was dispensed into $1.5 \mathrm{~mL}$ tubes $(1.0 \mathrm{~mL} /$ tube). The tubes were incubated for $30 \mathrm{~min}$ in heat blocks maintained statically at four different temperatures: $40^{\circ} \mathrm{C}, 50^{\circ} \mathrm{C}, 60^{\circ} \mathrm{C}$, or on ice. Subsequently, all tubes were rapidly cooled in an ice bath. For the negative controls, supernatant was prepared from hemolymph (Test 6-1) or macerated tissue (Test 6-2) of healthy animals and used without heat treatment. Each inoculum was injected into the adductor muscles of 5 healthy pearl oysters $(100 \mu \mathrm{l} /$ individual). The mortality was monitored during the experiments. The shell scores were determined on the surviving individuals 21 and 15 days after the injections in Tests 6-1 and 6-2, respectively.

\section{Histopathology}

Sampling for histopathology was conducted on days 5 and 10 after the inoculation of the first passage in the Test 4. For the 5-day samples, tissues were taken from the oysters used as donors for the 2nd passage for 5-day interval passages. For the 10-day samples, tissues were taken from the animals used as donors for the 2nd passage for 10-day interval passages. At each sampling, the mantle, gill, kidney, heart, adductor muscle, foot, and midgut (including the stomach and gonads) were dissected from 5 specimens after collecting the hemolymph. The tissues were fixed in Davidson's solution (Bell and Lightner, 1988), dehydrated through an ethanol series and embedded in paraffin. Two sets of $3 \mu \mathrm{m}$ sections were prepared from each tissue, stained with hematoxylin and eosin or MayGrunwald / Giemsa, and observed under a microscope.

217 


\section{Results}

219 Investigation of spontaneously occurring disease in farmed oysters

220 In the oysters obtained from pearl farmers in Mie and Ehime prefectures where summer atrophy occurred, 221 nacre abnormalities were observed in 45.6 81.6\% of the oysters (Table 2). Cultured pearl oysters from Mie

222 prefecture before the disease occurred, and wild pearl oysters from areas where pearl farming has never performed

223 and the disease has not been recorded, did not show the nacre abnormalities that are seen in the disease.

224

225

Test 1: Cohabitation and injection challenge using adult pearl oysters as the infection source

There were no significant differences in mortality between test groups (Table 3). Appearances of nacre abnormalities of the experimental groups were significantly higher than those of the corresponding negative controls, except for the cohabitation experiment at the low temperature (Table 3). Shell scores of the injection-challenged groups were significantly higher than those of the negative controls.

\section{Test 2: Injection challenge using juvenile pearl oysters as the infection source} prepared from diseased pearl oysters, death of the experimental animals started on the $11^{\text {th }}$ day after inoculation, and 7 out of 10 individuals died by the end of the experiment. Six of the seven dead specimens exhibited shell abnormalities, and the mean shell score obtained for the seven dead individuals was $1.7 \pm 0.4$. The abnormalities on the nacre were also confirmed in all three surviving individuals, and the mean shell score for the three was $3.3 \pm 0.7$. No abnormalities were observed in the shells of the surviving individuals in the negative control group.

\section{Test 3: Filterability}

The results are summarized in Table 5. Mortality was only found in the experimental and positive control groups. Nacre abnormalities were also mostly observed in the experimental and positive control animals, although slight abnormalities were observed in some control oysters. Thus, the disease was clearly reproduced only in the experimental and positive control groups including the experimental oysters injected with the hemolymph filtered through $0.1 \mu \mathrm{m}$ filter.

\section{Test 4: Serial passages}

247 Neither mortality nor nacre abnormalities were observed in the negative control group (Table 6). In the 1-hour 248 interval series, shell abnormalities were observed by the second passage, but no abnormalities were observed in the

$2493^{\text {rd }}$ passage. On the other hand, in the 5-day and 10-day interval passages, the nacre abnormalities were observed up 250 to the end of the experiments.

\section{Test 5: Chloroform sensitivity}

In both experiments, the nacre abnormalities appeared similarly in the two experimental groups irrespective of 


\section{Test 6: Thermal stability}

No abnormalities in the nacreous layer were observed in the groups injected with the inoculums incubated at $50^{\circ} \mathrm{C}$ and $60^{\circ} \mathrm{C}$ in Test 6-1, and in the group injected with the inoculum treated with heat at $60^{\circ} \mathrm{C}$ in Test 6-2 (Table $2598)$.

260

261

262

263

264

265

266

267

268

269

270

271

272

273

274

275

276

277

278

279

280

281

282

283

284

285

286

287

288

289

290

291

\section{Histopathology}

In the oysters sampled on day 10 , increased numbers of migrating cells were observed in the connective tissues in 4 out of 5 individuals, but no other significant histopathological changes were found in any of the observed specimens.

\section{Discussion}

The results of this study suggest that summer atrophy of Akoya pearl oyster is an infectious disease. The nacre abnormalities found in spontaneously affected oysters were reproduced in healthy pearl oysters that were reared with diseased oysters in 3 of the 4 experiments (Tests 1 and 2). Nacre abnormalities were also confirmed in the surviving oysters in all six infection tests with injections of the inoculum prepared from affected pearl oysters.

The mass mortality of juveniles and abnormalities in adult oysters in pearl culture farms are likely to be caused by the same causative agent, considering the results of the present study, in which the disease was reproduced either by affected adults or by affected 0 -year-old juveniles as the donors. Nevertheless, infection tests on juveniles should be conducted in future studies to see if mass mortality could be reproduced, since only adult oysters were used as recipients in this study.

The results of this study also suggest that the etiology of this disease is proliferative. Both in the 5-day and 10day interval passages, the nacre abnormalities were confirmed up to the end of the experiments. Therefore, the etiological agent of this disease probably proliferates within 5-10 days after inoculation to the amount that is enough to cause the disease in the next passage. In the 1-hour interval passages, however, none of the individuals in the third passage developed the abnormalities of nacre surface, although the nacre abnormalities were confirmed up to the second passage. The causative agent probably could not sufficiently propagate in 1 hour, and the disease appeared in the second passage was most likely caused by the causative agent that had been carried over from the injection in the first passage.

The etiological agent in the host body appears to decrease quickly as the oyster recovers. In previous studies, we could not reproduce the disease either by cohabitation or injection when pearl oysters with normal soft bodies were used as donors, despite that we obtained those donors from the group that had experienced summer atrophy and confirmed typical nacre abnormalities in those animals (Supplemental Tables 1 and 2). Therefore, to reproduce the disease, it seems important to use diseased oysters with atrophied soft bodies or oysters from populations that are currently experiencing mass mortality as the infection source.

Considering the filterability (Test 3), the sensitivity to chloroform (Test 5) and the thermal stability (Test 6) of the pathogen, the causative agent for summer atrophy seems to be a non-enveloped virus with a minor axis of less 
292 than $100 \mathrm{~nm}$, which is inactivated 50 or $60^{\circ} \mathrm{C}$ for $30 \mathrm{~min}$. In addition, the optimal temperature for the propagation of

293 the pathogen might be around $25{ }^{\circ} \mathrm{C}$ or more, since the disease was not clearly reproduced by cohabitation at 22-23

$294{ }^{\circ} \mathrm{C}$ in this study. This is supported by the fact that the spontaneous disease outbreaks occur during summer as stated

295 before. However, this requires further study.

296 We could not find any noticeable histopathological changes in the affected pearl oysters in the present study. In

297 fact, we have not observed any substantial histopathological changes that are common to spontaneously diseased

298 oysters presumably affected with summer atrophy so far. This seems peculiar for a disease with mass mortality

299 caused by an infectious agent. It is possible that we have overlooked some important histological changes, although

300 it would be clarified if the pathogen is definitively identified.

301 Several cases similar to summer atrophy have been reported in the genus Pinctada, but none are identical to the

302 disease. Birnavirus (Suzuki et al., 1998a) and "Akoya virus" (Miyazaki et al., 1999) were reported to infect $P$. fucata

303 in Japan, although the symptoms of summer atrophy were not observed with those virus infections. Moreover,

304 neither biochemical nor morphological characteristics have been reported for Akoya virus, and its existence itself is

305 uncertain. Akoya virus was reported to be the causative agent of Akoya oyster disease (AOD), although its

306 relationship with AOD has been refuted (Matsuyama et al., 2017). Virus infections have also been reported in $P$.

307 maxima (Pass et al., 1988; Norton e al., 1993). However, the characteristic viral inclusion bodies observed in these

308 studies were not found in this study, and hence, these viruses seem to be unrelated to summer atrophy of $P$. fucada.

309 Mass mortalities of unknown etiology has been reported in the members of the genus Pinctada (Wolf and

310 Sprague, 1978, Nasr, 1982, Comps et al., 2001, Jones et al., 2010). One of those, "syndrome 85" is similar to

311 summer atrophy in $P$. fucada, in that juvenile experience mass mortality and show symptoms that include deposition

312 of brown organic matter on the inner surface of the two valves in P. margaritifera (Comps et al., 2001). Unlike

313 summer atrophy, however, high mortality occurs irrespective of the age of the shells in syndrome 85, and the disease

314 is also characterized by granulomatous tissue formation (Comps et al., 2001). Another abnormal condition with

315 unknown etiology is oyster oedema disease (OOD). The disease caused mass mortality in P. maxima in Western

316 Australia in 2006 (Jones et al., 2010). Similar to summer atrophy, the mantle of OOD-affected oysters is contracted,

317 and histological responses are not observed (Jones et al., 2010). However, edema does not occur in summer atrophy.

318 Thus, summer atrophy of $P$. fucada seems to be a new infectious disease in the genus Pinctada, although it is

319 possible that the differences in the symptoms in those diseases with unknown etiology in Pinctada might be due to

320 the difference in the host species.

321 Abnormalities in shells of bivalves, which are often collectively called "shell disease", can be caused by a variety

322 of organisms, such as parasites (Martinelli et al., 2020, Farley, 1968), fungi (Friedman et al., 1997, Raghukumar and

323 Lande, 1988, Renault et al., 2002), bacteria (Elston and Leibovitz, 1980, Paillard and Maes, 1995, Elston et al., 1999,

324 Boettcher et al. 2005, Huang et al., 2019), and viruses (Momoyama et al., 1999, Matsuyama et al., 2020). Shell

325 disease in P. fucata has also been experimentally reproduced by inoculating viable Escherichia coli or the yeast

326 Saccharomyces cerevisiae into the extrapallial space of the valves (Huang et al., 2019). Since the responsible tissue

327 for shell formation is the mantle, these pathogens probably affect the activity of mantle, either directly or indirectly,

328 and lead to shell disease. Sano et al. (2021) compared the expression levels of five genes in the mantle of healthy $P$.

Peer] reviewing PDF | (2021:05:61828:2:0:NEW 19 Aug 2021) 
329 fucata and the animals affected with summer atrophy, and found decreased expression of the OT47 gene (tyrosinase 330 gene involved in the formation of periostracum (Zhang et al., 2006)) and increased expression of the msi31 gene

331 (shell matrix protein gene involved in the formation of the prismatic layer (Sudo et al., 1997)) in the diseased oysters.

332 The expression levels of these genes may be altered by the causative agent of the disease in the mantle. However, no

333 obvious histopathological change has been observed in the tissues of the diseased pearl oysters, including the mantle,

334 so far. It is therefore unknown whether the etiological agent of the disease exists in the mantle. To resolve these

335 issues and to identify the etiological agent, we are currently conducting experiments utilizing next-generation

336 sequencing.

337

338 Conclusions

This study was conducted to clarify the involvement of infectious agents in the mass mortality in juveniles and atrophy and mortality in adult pearl oysters (P. fucata) in the major pearl farming areas in Japan in 2019 and 2020.

341 The condition, or the disease, is referred to as "summer atrophy" here. The oysters recovered from the disease

342 exhibited deposition of brown materials and loss of luster on the inner nacreous surface of valves, which is usually

343 smooth and shiny. These shell abnormalities were reproduced in healthy pearl oysters either by injecting

344 hemolymph from affected oysters or by cohabitation with diseased specimens. The disease was successfully

345 reproduced through continual passages using hemolymph as the inoculum up to the 8 th passage. The cause of this

346 disease is hence considered to be a proliferative pathogen. In addition, pathogenicity was not affected by filtering the

347 inoculum through a $0.1 \mu \mathrm{m}$ filter or by chloroform treatment. Therefore, the etiological agent is likely to be a non-

348 enveloped virus with a diameter of less than $100 \mathrm{~nm}$. Definitive identification of this pathogen is the ongoing subject

349 of our study.

350

351

Acknowledgements

352

The authors would like to thank Mr. I. Kuriyama, Mie Prefecture Fisheries Research Institute, Dr. H.

353 Kawakami and Dr. T. Itano, Ehime Prefectural Fish Disease Control Center and Dr. S. Shirakashi, Kindai University

354 for their assistance for sampling pearl oyster.

355

356

\section{Figure legends}

357

358

Figure 1. Locations of major pearl farms and areas where healthy pearl oysters were obtained.

359

The prefectures painted in red and black indicate major pearl farming areas using P. fucata and areas where

360 healthy pearl oysters were obtained, respectively.

361

362

Figure 2. Appearances of diseased and healthy pearl oysters.

(A) A 1-year-old pearl oyster with summer atrophy. The soft body is atrophied and is contracted towards the 
365

366

367

368

369

370

371

372

373

374

375

376

377

378

379

380

381

382

383

384

385

386

387

388

389

390

391

392

393

394

395

396

397

398

399

400

401

pearl oysters affected by summer atrophy. Arrowheads indicate brown deposit on the nacre. (C) Zero-year-old pearl oysters affected by summer atrophy. Deposition of brownish material is seen on the nacre surface (white arrowheads), whereas shell spines are extending (yellow arrowheads). (D) A normal pearl oyster. The mantle covers the entire nacre surface. (E) A pearl oyster with black-spot shell disease. Dark, organic matter is deposited mainly from the dorsal edge to the central part on the nacre. This individual was sampled from the group affected by summer atrophy. Loss of luster (the white arrowhead) and slight pigmentation (the yellow arrowhead) seem to be the symptoms of summer atrophy. (F) A Pearl oyster with Akoya oyster disease. The soft body is atrophied and has turned reddish-brown in color. No abnormality is observed on the nacre.

Figure 3. Scoring the severity of disease

The severity of the disease was quantified according to the ratio of abnormal areas (deposition of brown pigment and loss of luster) to the total nacreous surface: score 0 , normal; score 1, the abnormal area is less than $30 \%$; score 2 , the abnormal area is larger than $30 \%$ and less than $70 \%$; and score 3 , the abnormal area is larger than $70 \%$.

In these photographs, the shell with score 1 has brown deposit (the white arrowheads) on the upper right, and the shell with score 2 has brown deposit on the upper left and bottom. In the shell with score 3, deposition was observed on the upper and lower areas where the mantle was located, and the surrounding large area of nacre has lost its luster (the yellow arrowheads).

Figure 4. Outline of the transmission experiments with serial passages

The serial passages were conducted with 3 different intervals: 1 hour, 5 days, and 10 days. Hemolymph was collected from 5 specimens in each cohort, pooled, and injected into the next group. The remaining 7 individuals in each cohort were sampled 3 weeks after inoculation to observe abnormalities of nacre surface.

\section{Supplemental data}

Infection tests using pearl oysters with shell abnormalities and normal soft bodies as the infection source.

Materials and Methods

1. Animals

One-year-old, healthy pearl oysters from Ishikawa Prefecture were used as the recipients. Two groups of oysters of different ages ( 1 and 2-year-old) that had experienced summer atrophy were obtained from 2 pearl oyster farms respectively in Mie Prefecture and used as the donors. The experiments were performed in $65 \mathrm{~L}$ tanks filled with $56 \mathrm{~L}$ of running seawater maintained at $25^{\circ} \mathrm{C}$ and filtered with a $1-\mu \mathrm{m}$ pore size filter. The oysters were fed with diatoms (Chaetoceros neogracile), five times a week.

Peer] reviewing PDF | (2021:05:61828:2:0:NEW 19 Aug 2021) 
403

404

405

406

407

408

409

410

411

412

413

414

415

416

417

418

419

420

421

422 Results

423

424

425

426

427

428

429

430

431

432

433

434

435

\section{References}

2. Infection test by cohabitation

Before the start of the test, five oysters from each of the donor groups and from the recipient group were randomly sampled and the shell scores were determined. Cohabitation tests were conducted separately, either by using 1-year-old oysters or 2-year-old oysters as the donors. Experimental tanks were duplicated for each donor group. The number of donor oysters in each tank was 4 for 1-year-old and 10 for 2-year-old animals. Twenty healthy oysters were reared with donors in each tank. For the negative control, ten healthy oysters were used as donors and reared similarly with 20 healthy oysters in the same tank. The negative control tanks were also duplicated. Five recipient individuals from each tank were sampled to determine the shell scores on days 42,63 , and 111 after the start of cohabitation, and the mean shell scores were calculated.

\section{Infection test by hemolymph injection}

Hemolymph was collected from the adductor muscles of 10 affected oysters of the 2-year-old group. The shell scores for these oysters were determined after collecting the hemolymph. The hemolymph was pooled, and the supernatant was obtained by centrifugation at $1200 \times \mathrm{g}$ for $10 \mathrm{~min}$. The supernatant was injected into the adductor muscles of 20 healthy oysters ( $100 \mu \mathrm{L} /$ oyster). For the negative control, the same volume of autoclaved seawater was injected into the adductor muscles of 20 healthy oysters and the oysters were similarly reared thereafter. Both experimental and control tanks were duplicated. On the 51st day after the injections, 10 individuals from each group were sampled and the mean shell score was calculated.

1. Infection test by cohabitation

The donor oysters showed no atrophy in the soft body. Nevertheless, abnormalities were observed on the nacre of all specimens. The mean shell scores for the 1- and 2-year-old, affected pearl oysters were 4.2 \pm 0.7 and $3.2 \pm 0.9$, respectively. These donor animals appeared to have recovered from atrophy. The mean shell scores for the recipient oysters after cohabitations with the donors was $0 \pm 0$ to $1.0 \pm 0.5$, which were not significantly different from those for the negative control groups (Supplemental Table 1).

\section{Infection test by hemolymph injection}

While none of the pearl oysters used for hemolymph collection exhibited atrophy of the soft body, the nacre of all oysters was abnormal. The mean shell score for the donor oysters was $5.0 \pm 0.6(\mathrm{~N}=10)$. The mean shell scores for the two recipient groups at the end of the experiment, however, were $0 \pm 0$ and $0.2 \pm 0.1$, which were not significantly different from the value of $0 \pm 0$ for the negative control groups (Supplemental Table 2). 
437 Boettcher, K. J., Geaghan, K. K., Maloy, A. P. \& Barber, B. J. Roseovarius crassostreae sp. nov., a member of the

438

439

440

441

442

443

444

445

446

447

448

449

450

451

452

453

454

455

456

457

458

459

460

461

462

463

464

465

466

467

468

469

470

471

472

473

Roseobacter clade and the apparent cause of juvenile oyster disease (JOD) in cultured Eastern oysters. International Journal of Systematic and Evolutionary Microbiology 55, 1531-1537 (2005).

Bell, T. A. \& Lightner, V. A Handbook of Normal Penaeid Shrimp Histology. Allen Press, Inc. Lawrence, Kansas (1988).

Comps, M., Herbaut, C., Fougerouse, A. \& Laporte, F. Progress in pathological characterization of Syndrome 85 in the black-lip pearl oyster Pinctada margaritifera. Aquatic Living Resources 14, 195-202 (2001).

Elston,R. \& Leibovitz L. Pathogenesis of Experimental Vibriosis in Larval American Oysters, Crassostrea virginica, Can JFish Aquat Sci 37 964-978 (1980).

Elston, R. A., Frelier, P. \& Cheney, D. Extrapallial abscesses associated with chronic bacterial infections in the intensively cultured juvenile Pacific oyster Crassostrea gigas. Diseases of aquatic organisms 37, 115-120 (1999).

Farley, C. A. Minchinia nelsoni (Haplosporida) disease syndrome in the American oyster Crassostrea virginica. The Journal of protozoology 15, 585-599 (1968).

Friedman, C. S., Grindley, R. \& Keogh, J. A. Isolation of a fungus from shell lesions of New Zealand abalone, Haliotis iris Martyn and H. australis Gmelin. Molluscan Research 18, 313-324 (1997).

Huang, J., Xie, L. \& Zhang, R. Shell repair and the potential microbial causal in a shell disease of the pearl oyster Pinctada fucata. Fish \& shellfish immunology 86, 934-941 (2019).

Iwanaga, S., Hirai, M. \& Hosokawa, H. Improved pearl quality and survival rate of operated-shells by using 1-yearold mother-shells of the pearl oyster, Pinctada fucata martensii. Aquaculture Science 56, 73-79 (2008).

Jones, J., Crockford, M., Creeper, J. \& Stephens, F. Histopathology of oedema in pearl oysters Pinctada maxima. Diseases of aquatic organisms 91, 67-73 (2010).

Kurokawa, T., Suzuki, T., Okauchi, M., Miwa, S., Nagai, K., Nakamura, K., Honjo, T., Nakajima, K., Ashida, K. \& Funakoshi, S. Experimental infections of a disease causing mass mortalities of Japanese pearl oyster Pinctada fucata martensii by tissue transplantation and cohabitation. Nippon Suisan Gakkaishi (Japanese Edition) 65, 241-251 (1999).

Martinelli, J. C., Lopes, H. M., Hauser, L., Jimenez-Hidalgo, I., King, T. L., Padilla-Gamiño, J. L., Rawson, P., Spencer, L. H., Williams, J. D. \& Wood, C. L. Confirmation of the shell-boring oyster parasite Polydora websteri (Polychaeta: Spionidae) in Washington State, USA. Scientific reports 10, 1-14 (2020).

Matsuyama, T., Yasuike, M., Fujiwara, A., Nakamura, Y., Takano, T., Takeuchi, T., Satoh, N., Adachi, Y., Tsuchihashi, Y., Aoki, H., Odawara, K., Iwanaga, S., Kurita, J., Kamaishi, T. \& Nakayasu, C. A Spirochaete is suggested as the causative agent of Akoya oyster disease by metagenomic analysis. PloS one 12, e0182280 (2017).

Matsuyama, T., Matsuura, Y., Inada, M., Takano, T., Nakayasu, C., Sakai, T., Terashima, S., Yasuike, M., Fujiwara, A., Nakamura, Y., Tsuhchihashi, Y., Odawara, K., Iwanaga, S. \& Masaoka, T. An Epidemiological study of Akoya oyster disease using polymerase chain reaction targeting Spirochaetes genes. Fish Pathology 53, 63-70 (2018).

Peer] reviewing PDF | (2021:05:61828:2:0:NEW 19 Aug 2021) 
474 Matsuyama, T., Takano, T., Nakayasu, C., Odawara, K., Tsuchihashi, Y., Tanaka, S., Yasuike, M., Fujiwara, A.,

475

476

477

478

479

480

481

482

483

484

485

486

487

488

489

490

491

492

493

494

495

496

497

498

499

500

501

502

503

504

505

506

507

508

509

510
Nakamura, Y. \& Masaoka, T. Spatiotemporal dynamics of Spirochaeta, the putative etiologic agent of Akoya oyster disease in pearl oysters, as determined by quantitative PCR. Aquaculture 513, 734433 (2019).

Matsuyama, T., Takano, T., Nishiki, I., Fujiwara, A., Kiryu, I., Inada, M., Sakai, T., Terashima, S., Matsuura, Y., Isowa, K. \& Nakayasu, C. A novel Asfarvirus-like virus identified as a potential cause of mass mortality of abalone. Scientific reports 10, 1-12 (2020).

Miyazaki, T., Goto, K., Kobayashi, T., Kageyama, T. \& Miyata, M. Mass mortalities associated with a virus disease in Japanese pearl oysters Pinctada fucata martensii. Diseases of Aquatic Organisms 37, 1-12 (1999).

Momoyama, K., Nakatsugawa, T. \& Yurano, N. Mass mortalities of juvenile abalones, Haliotis spp., caused by amyotrophia. Fish pathology 34, 7-14 (1999).

Nasr, D. H. Observations on the mortality of the pearl oyster, Pinctada margaritifera, in Dongonab Bay, Red Sea. Aquaculture 28, 271-281(1982).

Norton, J., Shepherd, M. \& Prior, H. Papovavirus-like infection of the golden-lipped pearl oyster, Pinctada maxima, from the Torres Strait, Australia. Journal of Invertebrate Pathology 62, 198-200 (1993).

Paillard, C. \& Maes, P. The brown ring disease in the Manila clam, Ruditapes philippinarum: I. Ultrastructural alterations of the periostracal lamina. Journal of invertebrate pathology 65, 91-100 (1995).

Pass, D., Perkins, F. \& Dybdahl, R. Virus like particles in the digestive gland of the pearl oyster (Pinctada maxima). Journal of invertebrate pathology (Print) 51, 166-167 (1988).

Raghukumar, C. \& Lande, V. Shell disease of rock oyster Crassostrea cucullata. Diseases of aquatic organisms 4 , 77-81 (1988).

Renault, T., Chollet, B., Cochennec, N. \& Gerard, A. Shell disease in eastern oysters, Crassostrea virginica, reared in France. Journal of invertebrate pathology 79, 1-6 (2002).

Sakaguchi S. Studies on the life-history of the trematode parasite in pearl oyster, Pinctada martensii, and on the hindrance for pearl culture. Bulletin of Natural Pearl Research Laboratory13: 1635-1688 (1968).

Sano, M., Kuriyama, I. \& Komaru, A. Characteristics of mantle gene expression and bacterial flora in Akoya pearl oysters Pinctada fucata with mantle atrophy. Aquaculture Science 69, 13-20 (2021).

Sakatoku, A., Fujimura, T., Ito, M., Takashima, S. \& Isshiki, T. Newly isolated bacterium Tenacibaculum sp. strain Pbs-1 from diseased pearl oysters is associated with black-spot shell disease. Aquaculture 493, 61-67 (2018).

Sudo, S., Fujikawa, T., Nagakura, T., Ohkubo, T., Sakaguchi, K., Tanaka, M., Nakashima, K. \& Takahashi,T. Structures of mollusc shell framework proteins. Nature 387, 563-564 (1997).

Suzuki, S., Kamakura, M. \& Kusuda, R. Isolation of birnavirus from Japanese pearl oyster Pinctada fucata. Fisheries science 64, 342-343 (1998a).

Suzuki, S., Utsunomiya, I. \& Kusuda, R. Experimental infection of marine birnavirus strain JPO-96 to Japanese pearl oyster Pinctada fucata. Bulletin of marine sciences and fisheries, Kochi University 18, 39-41 (1998b).

Wolf, P. H., \& Sprague, V. An unidentified protistan parasite of the pearl oyster, Pinctada maxima, in tropical Australia. Journal of invertebrate pathology 31, 262-263 (1978).

Peer) reviewing PDF | (2021:05:61828:2:0:NEW 19 Aug 2021) 
511 Zhang, C., Xie, L., Huang, J., Chen, L. \& Zhang, R. A novel putative tyrosinase involved in periostracum formation

512 from the pearl oyster (Pinctada fucata). Biochemical and biophysical research communications 342, 632-

513 639 (2006).

514 


\section{Figure 1}

Locations of major pearl farms and areas where healthy pearl oysters were obtained.

The prefectures painted in red and black indicate major pearl farming areas using $P$. fucata and areas where healthy pearl oysters were obtained, respectively. 


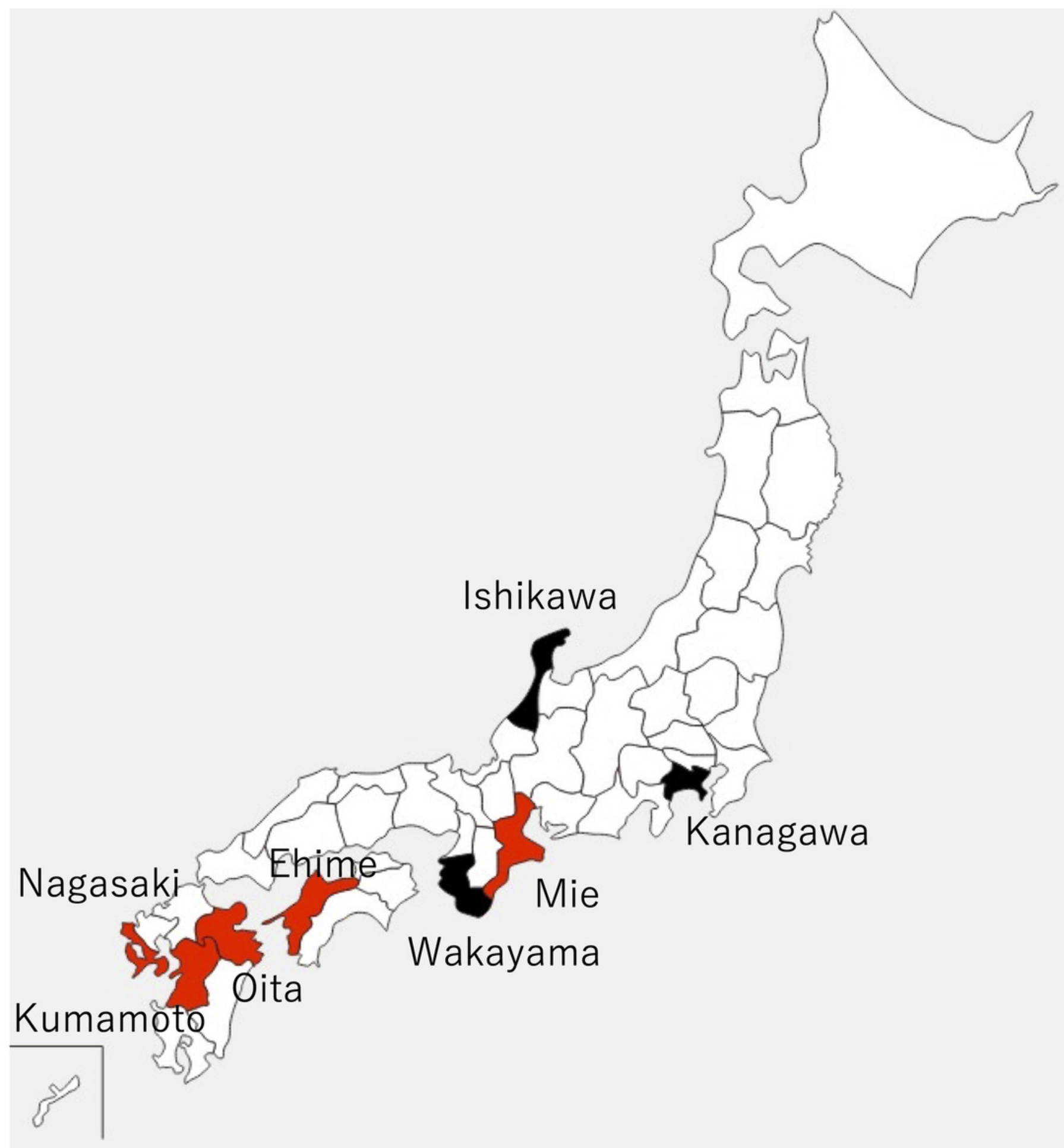




\section{Figure 2}

Appearances of diseased and healthy pearl oysters.

(A) A 1-year-old pearl oyster with summer atrophy. The soft body is atrophied and is contracted towards the dorsal margin. The arrowhead indicates brown deposit on the nacre along the mantle edge. (B) Nacre of 2-year-old pearl oysters affected by summer atrophy. Arrowheads indicate brown deposit on the nacre. (C) Zero-year-old pearl oysters affected by summer atrophy. Deposition of brownish material is seen on the nacre surface (white arrowheads), whereas shell spines are extending (yellow arrowheads). (D) A normal pearl oyster. The mantle covers the entire nacre surface. (E) A pearl oyster with black-spot shell disease. Dark, organic matter is deposited mainly from the dorsal edge to the central part on the nacre. This individual was sampled from the group affected by summer atrophy. Loss of luster (the white arrowhead) and slight pigmentation (the yellow arrowhead) seem to be the symptoms of summer atrophy. (F) A Pearl oyster with Akoya oyster disease. The soft body is atrophied and has turned reddish-brown in color. No abnormality is observed on the nacre. 


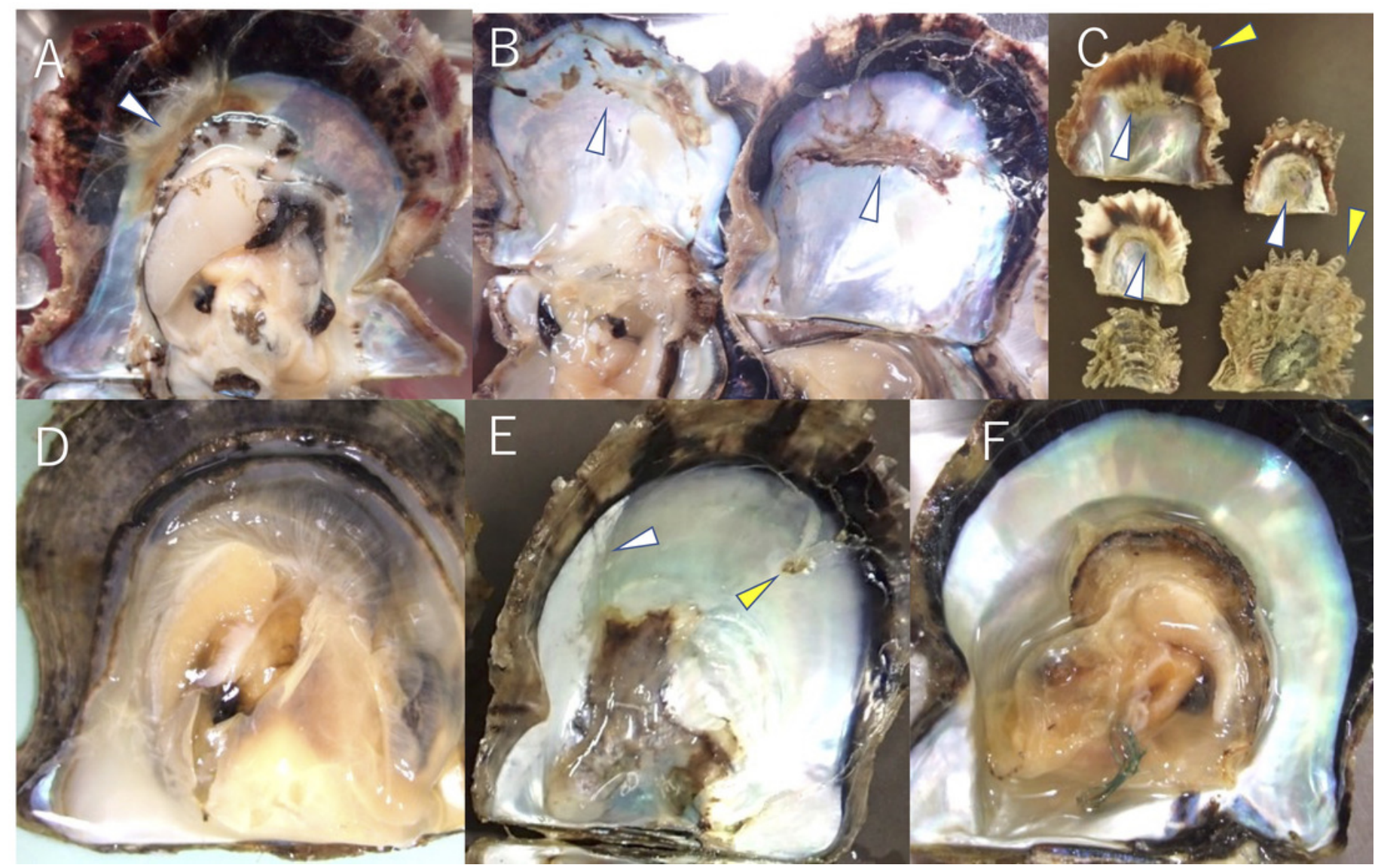




\section{Figure 3}

Scoring the severity of disease

The severity of the disease was quantified according to the ratio of abnormal areas (deposition of brown pigment and loss of luster) to the total nacreous surface: score 0 , normal; score 1, the abnormal area is less than $30 \%$; score 2, the abnormal area is larger than $30 \%$ and less than $70 \%$; and score 3, the abnormal area is larger than $70 \%$. In these photographs, the shell with score 1 has brown deposit (the white arrowheads) on the upper right, and the shell with score 2 has brown deposit on the upper left and bottom. In the shell with score 3, deposition was observed on the upper and lower areas where the mantle was located, and the surrounding large area of nacre has lost its luster (the yellow arrowheads). 


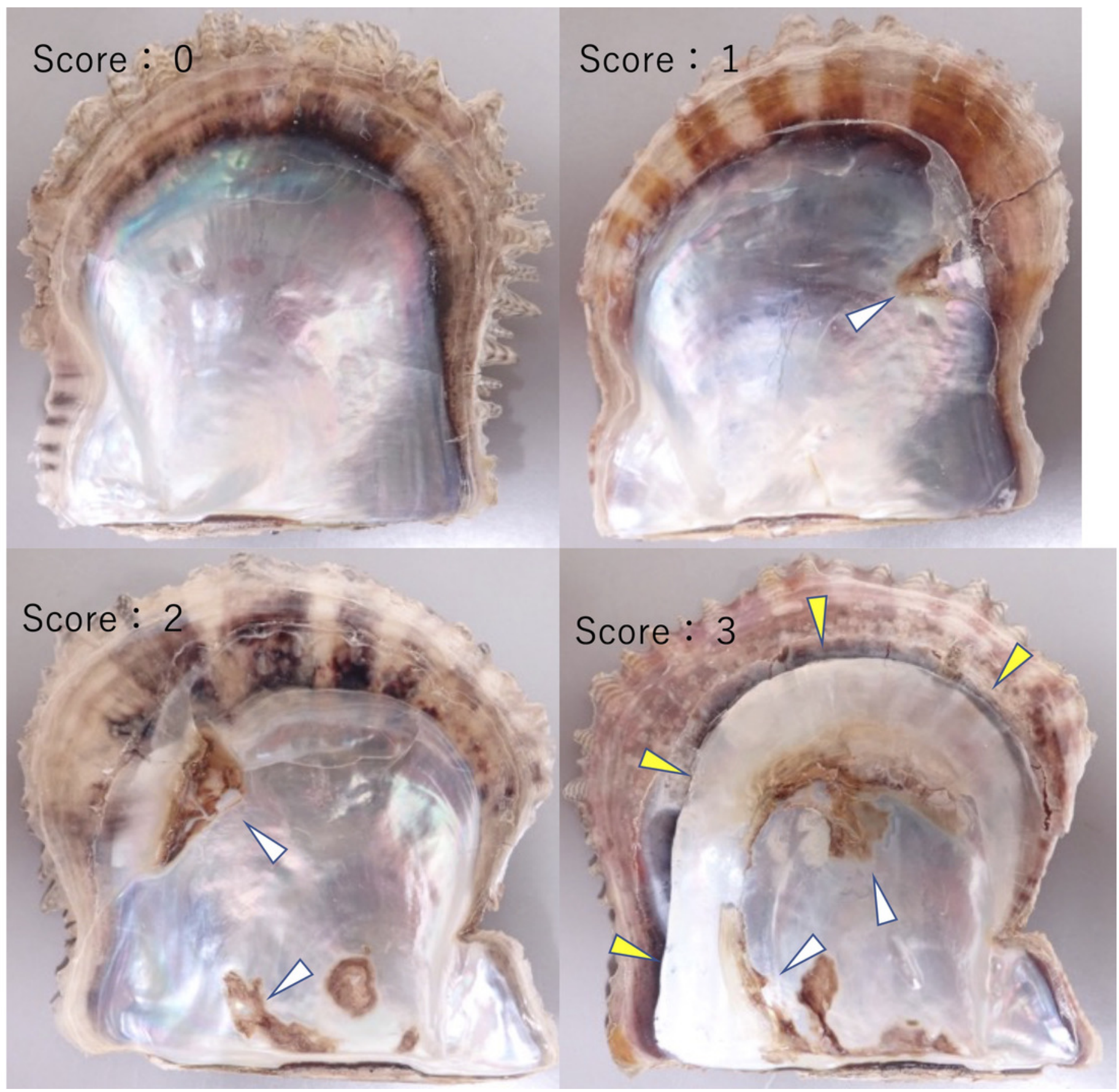


Figure 4

Outline of the transmission experiments with serial passages

The serial passages were conducted with 3 different intervals: 1 hour, 5 days, and 10 days. Hemolymph was collected from 5 specimens in each cohort, pooled, and injected into the next group. The remaining 7 individuals in each cohort were sampled 3 weeks after inoculation to observe abnormalities of nacre surface.

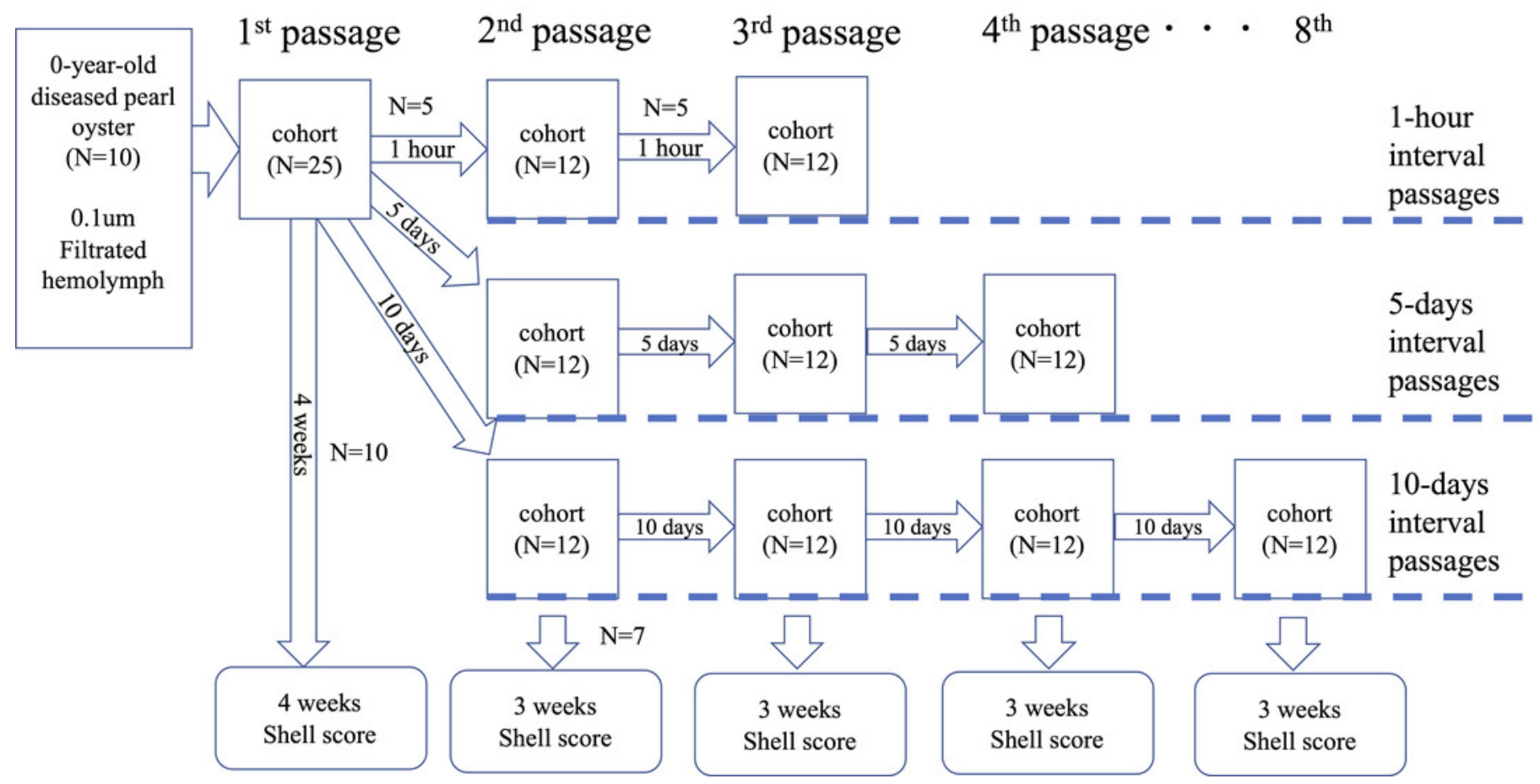




\section{Table $\mathbf{1}$ (on next page)}

Summary of pearl oysters used

*: The number of oysters in which nacre abnormality was observed / the number of oysters sacrificed from each group immediately before the start of the experimets. No atrophy in the soft tissues was observed in the recipient groups. ": The number of oysters in which the soft body was atrophied / the number of oysters sacrificed from each group immediately before the start of the experiments. Nacre abnormalities remain after the oyster recovered from the disease, and hence, it cannot be used to judge if the oyster is diseased at the time of observation. NM: Not measured 
Table 1. Summary of pearl oysters used $\square$

$\square$

\begin{tabular}{|c|c|c|c|c|c|c|c|c|}
\hline \multicolumn{5}{|c|}{ Healthy pearl oysters (Recipients) } & \multirow{2}{*}{$\begin{array}{c}\square \\
\text { Nacre } \\
\text { abnormalities } \\
*\end{array}$} & \multirow{2}{*}{$\begin{array}{l}\square \\
\text { Mean } \\
\text { shell } \\
\text { score }\end{array}$} & \multirow[t]{2}{*}{$\square$} & \multirow[t]{3}{*}{$\square$} \\
\hline $\begin{array}{l}\text { Infection } \\
\text { xperiments }\end{array}$ & $\begin{array}{c}\text { Collection } \\
\text { sites }\end{array}$ & $\begin{array}{l}\text { Age } \\
\text { (years } \\
\text { old) }\end{array}$ & $\begin{array}{l}\text { Range in shell } \\
\text { width (mm, } \\
\text { mean } \pm \mathrm{SD})\end{array}$ & $\begin{array}{c}\text { Prevalence } \\
\text { of } \\
\text { atrophy }\end{array}$ & & & & \\
\hline Test 1 & Ishikawa & 1 & $\begin{array}{c}45-57 \\
(49.3 \pm 3.7)\end{array}$ & $0 / 10$ & $0 / 10$ & $0 \pm 0$ & & \\
\hline Test 2 & Ishikawa & 1 & $\begin{array}{c}51-63 \\
(59.6 \pm 3.1)\end{array}$ & $0 / 10$ & $2 / 10$ & $0.4 \pm 0.3$ & & \\
\hline Test 3 & Kanagawa & 1 & $\begin{array}{c}45-56 \\
(49.8 \pm 3.6)\end{array}$ & $0 / 5$ & $0 / 5$ & $0 \pm 0$ & & \\
\hline Test 4 & Kanagawa & 1 & $\begin{array}{c}55-68 \\
(61.8 \pm 2.3)\end{array}$ & $0 / 10$ & $0 / 10$ & $0 \pm 0$ & & \\
\hline Test 5-1 & Kanagawa & 1 & ditto & $0 / 10$ & $0 / 10$ & $0 \pm 0$ & & \\
\hline Test 5-2 & Kanagawa & 1 & $\begin{array}{c}51-64 \\
(55.0 \pm 5.6)\end{array}$ & $0 / 5$ & $0 / 5$ & $0 \pm 0$ & & \\
\hline Test 6-1 & Kanagawa & 2 & $\begin{array}{c}51-65 \\
(57.6 \pm 1.4)\end{array}$ & $0 / 5$ & $0 / 5$ & $0 \pm 0$ & & \\
\hline Test 6-2 & Kanagawa & 3 & $\begin{array}{c}50-75 \\
(15.8 \pm 0.8)\end{array}$ & $0 / 5$ & $1 / 20$ & $0.1 \pm 0.1$ & $\square$ & $\square$ \\
\hline
\end{tabular}

Source of infection (Donors)

\begin{tabular}{|c|c|c|c|c|c|c|c|c|}
\hline $\begin{array}{l}\text { Infection } \\
\text { experiments }\end{array}$ & $\begin{array}{c}\text { Collection } \\
\text { sites }\end{array}$ & $\begin{array}{l}\text { Age } \\
\text { (years } \\
\text { old) }\end{array}$ & $\begin{array}{l}\text { Range in shell } \\
\text { width (mm, } \\
\text { mean } \pm \mathrm{SD})\end{array}$ & $\begin{array}{l}\text { Prevalence } \\
\text { of } \\
\text { atrophy }\end{array}$ & $\begin{array}{c}\text { Nacre } \\
\text { abnormalities } \\
*\end{array}$ & $\begin{array}{l}\text { Mean } \\
\text { shell } \\
\text { score }\end{array}$ & $\begin{array}{l}\text { Source of } \\
\text { inoculum }\end{array}$ & Note \\
\hline
\end{tabular}




\begin{tabular}{|c|c|c|c|c|c|c|c|c|}
\hline Test 1 & Mie & 3 & $\begin{array}{c}73-60 \\
(65.0 \pm 1.5)\end{array}$ & $3 / 10$ & $7 / 10$ & $2.3 \pm 0.6$ & Hemolymph & There are traces of previous year. \\
\hline Test 2 & Mie & 0 & NM & $5 / 10$ & $0 / 10$ & $0 \pm 0$ & $\begin{array}{l}\text { Supernatant } \\
\text { of macerated } \\
\text { tissue }\end{array}$ & $\begin{array}{l}\text { Cumulative mortality rate at the time } \\
\text { of sampling was ca. } 20 \% \text {. No deaths } \\
\text { up to } 6 \text { days before sampling. }\end{array}$ \\
\hline Test 3 & Mie & 0 & $\begin{array}{c}27-32 \\
(29.2 \pm 1.2)\end{array}$ & $2 / 10$ & $4 / 10$ & $1.3 \pm 1.1$ & $\begin{array}{l}\text { Supernatant } \\
\text { of macerated } \\
\text { tissue }\end{array}$ & $\begin{array}{l}\text { Nine days before the experiment, } 9 \text { out } \\
\text { of } 10 \text { individuals were atrophied. } \\
\text { Mortality rate unknown. }\end{array}$ \\
\hline Test 4 & Mie & 0 & $\begin{array}{c}26-45 \\
(33.5 \pm 2.0)\end{array}$ & $2 / 10$ & NM & NM & $\begin{array}{l}\text { Supernatant } \\
\text { of macerated } \\
\text { tissue }\end{array}$ & The same lot as in Test 3 were used. \\
\hline Test 5-1 & Mie & 0 & $\begin{array}{c}28-41 \\
(32.0 \pm 3.3)\end{array}$ & $2 / 10$ & NM & NM & $\begin{array}{l}\text { Supernatant } \\
\text { of macerated } \\
\text { tissue }\end{array}$ & The same lot as in Test 3 were used. \\
\hline Test 5-2 & $\begin{array}{c}\text { Experimentally } \\
\text { infected }\end{array}$ & 1 & $\begin{array}{c}50-67 \\
(58.6 \pm 3.1)\end{array}$ & $4 / 5$ & $0 / 5$ & $0 \pm 0$ & Hemolymph & Obtained from Test 4 \\
\hline Test 6-1 & $\begin{array}{c}\text { Experimentally } \\
\text { infected }\end{array}$ & 1 & $\begin{array}{c}52-61 \\
(56.0 \pm 2.6)\end{array}$ & $1 / 3$ & $0 / 3$ & $0 \pm 0$ & Hemolymph & Obtained from Test 4 \\
\hline Test 6-2 & Mie & 0 & $\begin{array}{c}12-20 \\
(15.8 \pm 0.8)\end{array}$ & $4 / 10$ & $7 / 10$ & $1.7 \pm 0.5$ & $\begin{array}{l}\text { Supernatant } \\
\text { of macerated } \\
\text { tissue }\end{array}$ & $\begin{array}{l}\text { Cumulative mortality rate at the time } \\
\text { of sampling was ca. } 33.3 \% \text {. No deaths } \\
\text { up to } 2 \text { days before sampling. }\end{array}$ \\
\hline
\end{tabular}

*: The number of oysters in which nacre abnormality was observed / the number of oysters sacrificed from each group immediately before the start of the experimets. No atrophy in the soft tissues was observed in the recipient groups.

\#: The number of oysters in which the soft body was atrophied / the number of oysters sacrificed from each group immediately before the start of the experiments. Nacre abnormalities remain after the oyster recovered from the disease, and hence, it cannot be used to judge if the oyster is diseased at the time of observation. 
NM: Not measured 


\section{Table 2 (on next page)}

Prevalence of atrophy and nacre abnormalities of the pearl oysters collected in different regions and ages

Nacre abnormalities and mean shell score were calculated for the incidence and score per shell, not per individual. ${ }^{\square}$ : The number of oysters in which the soft body was atrophied / the number of oysters sacrificed from each group immediately before the start of the experiments. Nacre abnormalities remain after the oyster recovered from the disease, and hence, it cannot be used to judge if the oyster is diseased at the time of observation. $\square$ : The number of valves in which nacre abnormality was observed / the number of tested valves from each group. !: Valves stored in a dry state at room temperature were observed on 2021.7.6. $t$ : Nature of pigmentation was much darker than those typically found in the oysters affected by summer atrophy and rather similar to that of black-spot shell disease. NM: Not measured 
Table 2 Prevalence of atrophy and nacre abnormalities of the pearl oysters collected in different regions and ages

\begin{tabular}{|c|c|c|c|c|c|c|}
\hline $\begin{array}{c}\text { Collection } \\
\text { dates }\end{array}$ & Collection sites & $\begin{array}{c}\text { Age (years } \\
\text { old) }\end{array}$ & $\begin{array}{l}\text { Range in shell } \\
\text { width (mean } \pm \\
\text { SD) }\end{array}$ & $\begin{array}{c}\text { Prevale } \\
\text { nce of } \\
\text { atrophy } \\
*\end{array}$ & $\begin{array}{c}\text { Nacre } \\
\text { abnormali } \\
\text { ties/valve } \\
\#\end{array}$ & $\begin{array}{c}\text { Mean } \\
\text { shell } \\
\text { score/val } \\
\text { ve }\end{array}$ \\
\hline \multicolumn{7}{|c|}{ Summer atrophy-free area } \\
\hline 2019.8 .23 & Ishikawa & 1 & $\begin{array}{c}49-67 \\
(58.5 \pm 1.0)\end{array}$ & $0 / 40$ & $\begin{array}{l}0 / 80 \\
(0 \%)\end{array}$ & $0 \pm 0$ \\
\hline 2020.6 .4 & Ishikawa & 1 & $\begin{array}{c}42-66 \\
(56.0 \pm 1.8)\end{array}$ & $0 / 40$ & $\begin{array}{l}2 / 40 \\
(5 \%)\end{array}$ & $\begin{array}{c}0.05 \pm \\
0.04\end{array}$ \\
\hline 2019.10 .22 & Wakayama & $0-2$ & $\begin{array}{c}29-55 \\
(44.6 \pm 2.5)\end{array}$ & $0 / 16$ & $0 / 32$ & $0 \pm 0$ \\
\hline 2019.11.1 & Wakayama & $0-2$ & $\begin{array}{c}29-55 \\
(44.6 \pm 2.5)\end{array}$ & $0 / 20$ & $0 / 40$ & $0 \pm 0$ \\
\hline 2020.9 .10 & Kanagawa & 1 & $\begin{array}{c}45-60 \\
(58.8 \pm 5.8)\end{array}$ & $0 / 30$ & $1 / 60^{\dagger}$ & $\begin{array}{c}0.03 \pm \\
0.02\end{array}$ \\
\hline 2020.10 .21 & Kanagawa & 1 & $\begin{array}{c}51-73 \\
(61.9 \pm 3.8)\end{array}$ & $0 / 30$ & $0 / 60$ & $0 \pm 0$ \\
\hline
\end{tabular}

\section{Summer atrophy-epidemic area}

\section{Before summer atrophy epidemic}

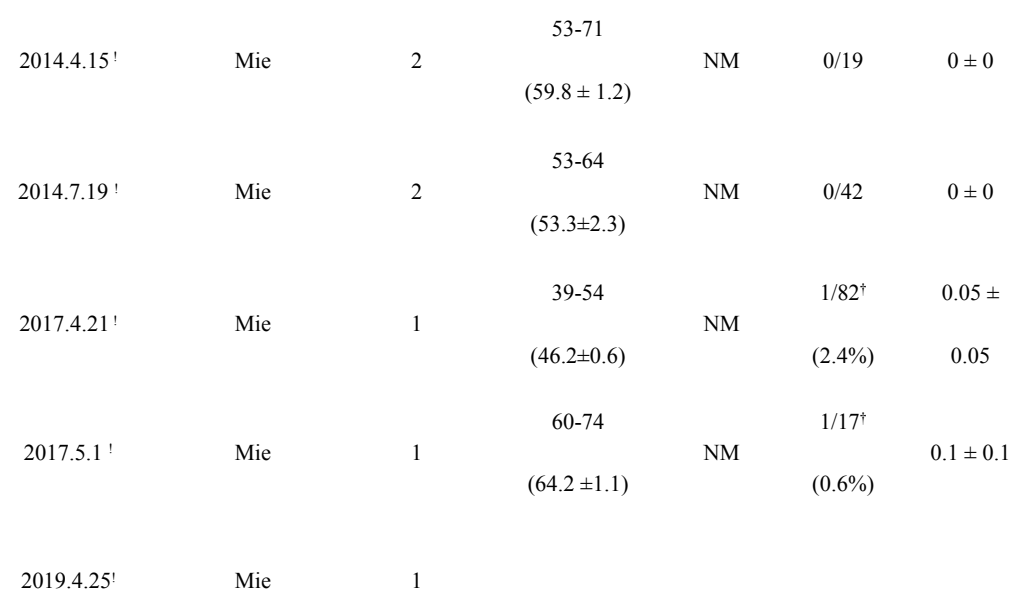

\section{After summer atrophy epidemic}

\begin{tabular}{|c|c|c|c|c|c|c|c|}
\hline \multirow{3}{*}{2019.8 .23} & & & $41-55$ & & $16 / 20$ & & The cumulative mortality rate of 0 -year- \\
\hline & Mie & 1 & $(48.5 \pm 1.7)$ & $5 / 10$ & $(80 \%)$ & $1.9 \pm 0.4$ & old oysters at the end of the mass \\
\hline & & & & & & & mortality was more than $50 \%$. \\
\hline 2019.9.19 & Mie & 0 & $27-42$ & NM & $17 / 30$ & $1.2 \pm 0.3$ & Randomly sampled, independent of \\
\hline
\end{tabular}




\begin{tabular}{|c|c|c|c|c|c|c|c|}
\hline & & & $(34.8 \pm 0.7)$ & & $(56.7 \%)$ & & disease onset. \\
\hline 2019.10 .24 & Mie & 0 and 1 & $\begin{array}{c}14-58 \\
(29.9 \pm 3.0)\end{array}$ & NM & $\begin{array}{l}31 / 38 \\
(81.6 \%)\end{array}$ & $1.6 \pm 0.2$ & $\begin{array}{l}\text { The cumulative mortality rate of } 0 \text {-year- } \\
\text { old oysters at the end of the mass } \\
\text { mortality was ca. } 70 \% \text {. }\end{array}$ \\
\hline 2019.11 .20 & Mie & 1 & $\begin{array}{l}50-57 \\
(53.6 \pm 0.5)\end{array}$ & NM & $\begin{array}{l}11 / 20 \\
(55 \%)\end{array}$ & $1.3 \pm 0.3$ & $\begin{array}{l}\text { Randomly sampled, independent of } \\
\text { disease onset. }\end{array}$ \\
\hline 2020.3.11 & Mie & 1 & $\begin{array}{c}50-68 \\
(56.1 \pm 1.4)\end{array}$ & $0 / 10$ & $\begin{array}{l}13 / 20 \\
(65 \%)\end{array}$ & $1.1 \pm 0.3$ & $\begin{array}{l}\text { Randomly sampled, independent of } \\
\text { disease onset. }\end{array}$ \\
\hline 2020.6 .24 & Mie & 1 & $\begin{array}{c}53-69 \\
(59.0 \pm 0.6)\end{array}$ & $7 / 44$ & $\begin{array}{l}24 / 44 \\
(54.5 \%)\end{array}$ & $0.9 \pm 0.2$ & $\begin{array}{l}\text { Obtained a few days after the pearl farmer } \\
\text { found the atrophy. Cumulative mortality } \\
\text { rate at the time of sampling was ca. } 20 \% \text {. }\end{array}$ \\
\hline 2021.6 .23 & Mie & 1 & $\begin{array}{c}25-66 \\
(47.8 \pm 1.8)\end{array}$ & NM & $\begin{array}{l}22 / 36 \\
(61.1 \%)\end{array}$ & $1.1 \pm 0.2$ & $\begin{array}{l}\text { Obtained a few days after the pearl farmer } \\
\text { found the atrophy. }\end{array}$ \\
\hline 2019.8.29 & Ehime & 1 & $\begin{array}{c}24-58 \\
(39.5 \pm 2.3)\end{array}$ & NM & $\begin{array}{l}33 / 48 \\
(68.8 \%)\end{array}$ & $1.3 \pm 0.2$ & $\begin{array}{l}\text { The cumulative mortality rate of } 0 \text {-year- } \\
\text { old oysters reared at the farm at the time } \\
\text { of sampling was ca. } 33.3 \% \text {. }\end{array}$ \\
\hline $2019.10 .17^{!}$ & Ehime & 0 & $\begin{array}{l}26-45 \\
(39.4 \pm 0.4)\end{array}$ & NM & $\begin{array}{l}39 / 68 \\
(45.6 \%)\end{array}$ & $1.2 \pm 0.2$ & $\begin{array}{l}\text { Randomly sampled, independent of } \\
\text { disease onset. }\end{array}$ \\
\hline 2019.10 .17 & Ehime & 1 & $\begin{array}{l}50-70 \\
(59.9 \pm 0.6)\end{array}$ & $5 / 30$ & $\begin{array}{l}36 / 60 \\
(60 \%)\end{array}$ & $1.4 \pm 0.2$ & $\begin{array}{l}\text { Randomly sampled, independent of } \\
\text { disease onset. }\end{array}$ \\
\hline 2020.9.17! & Ehime & $1-2$ & $\begin{array}{c}51-75 \\
(61.3 \pm 2.8)\end{array}$ & NM & $\begin{array}{l}7 / 10 \\
(70 \%)\end{array}$ & $1.4 \pm 0.4$ & $\begin{array}{l}\text { Randomly sampled, independent of } \\
\text { disease onset. }\end{array}$ \\
\hline
\end{tabular}

Nacre abnormalities and mean shell score were calculated for the incidence and score per shell, not per individual.

*: The number of oysters in which the soft body was atrophied / the number of oysters sacrificed from each group immediately before the start of the experiments. Nacre abnormalities remain after the oyster recovered from the disease, and hence, it cannot be used to judge if the oyster is diseased at the time of observation.

\#: The number of valves in which nacre abnormality was observed / the number of tested valves from each group.

!: Valves stored in a dry state at room temperature were observed on 2021.7.6.

$\dagger$ : Nature of pigmentation was much darker than those typically found in the oysters affected by summer atrophy and rather similar to that of black-spot shell disease.

NM: Not measured 


\section{Table 3 (on next page)}

Test 1: Cohabitation or injection with infected adult pearl oysters as the source of infection at two water temperatures

*: Significantly different from the negative control group (Fisher's exact test $p<0.05)$ \#:

Significantly different from the negative control group (Mann-Whitney U-test $p<0.05$ ) '; The number of oysters in which nacre abnormality was observed/the number of surviving oysters 
Table 3 Test 1: Cohabitation or injection with infected adult pearl oysters as the source of infection at two water temperatures

\begin{tabular}{|c|c|c|c|c|c|}
\hline \multirow[t]{3}{*}{ Water temperature $\square 22-23^{\circ} \mathrm{C}$} & & $\square$ & $\square$ & $\square$ & $\square$ \\
\hline & \multicolumn{2}{|c|}{ Infection experiments } & \multicolumn{3}{|c|}{ Negative controls } \\
\hline & Cohabitation & Injection & $\square$ & Cohabitation & Injection \\
\hline $\begin{array}{l}\text { Mortality } \\
\text { (dead/examined) }\end{array}$ & $1 / 14$ & $2 / 14$ & & $2 / 14$ & $1 / 14$ \\
\hline Nacre abnormalities! & $2 / 13$ & $9 / 12^{*}$ & & $1 / 12$ & $1 / 13$ \\
\hline Mean shell scores of survivors & $0.5 \pm 0.3$ & $2.8 \pm 0.4^{\#}$ & $\square$ & $0.3 \pm 0.1$ & $0.07 \pm 0.07$ \\
\hline$\square$ & $\square$ & $\square$ & $\square$ & $\square$ & \\
\hline \multirow[t]{3}{*}{ Water temperature $\square 25^{\circ} \mathrm{C}$} & & $\square$ & $\square$ & $\square$ & $\square$ \\
\hline & \multicolumn{2}{|c|}{ Infection experiments } & & \multicolumn{2}{|c|}{ Negative controls } \\
\hline & Cohabitation & Injection & $\square$ & Cohabitation & Injection \\
\hline $\begin{array}{l}\text { Mortality } \\
\text { (dead/examined) }\end{array}$ & $0 / 14$ & $1 / 14$ & & $1 / 14$ & $0 / 14$ \\
\hline Nacre abnormalities! & $5 / 14^{*}$ & $9 / 13^{*}$ & & $1 / 13$ & $0 / 14$ \\
\hline Mean shell scores of survivors & $0.9 \pm 0.4$ & $2.3 \pm 0.4^{\#}$ & $\square$ & $0.07 \pm 0.07$ & $0 \pm 0$ \\
\hline
\end{tabular}

*: Significantly different from the negative control group (Fisher's exact test $\mathrm{p}<0.05)$

\#: Significantly different from the negative control group (Mann-Whitney U-test $p<0.05$ )

!; The number of oysters in which nacre abnormality was observed/the number of surviving oysters 


\section{Table 4 (on next page)}

Test 2: Injection with juvenile pearl oysters as the source of infection

*: Significantly different from the negative control group (Fisher's exact test $p<0.05$ ) '; The number of oysters in which nacre abnormality was observed/the number of observed oysters 
Table 4 Test 2: Injection with juvenile pearl oysters as the source of infection

Negative
Infection experiments

Mortality
(dead/examined)

Nacre abnormalities of dead!

Nacre abnormalities of survivor!

Mean shell scores of dead oysters

Mean shell scores of survivors

$\begin{array}{ll}7 / 10^{*} & 0 / 10\end{array}$

*: Significantly different from the negative control group (Fisher's exact test $\mathrm{p}<0.05$ ) [

!; The number of oysters in which nacre abnormality was observed/the number of observed oysters 


\section{Table 5 (on next page)}

Test 3: Filterability of causative agent of summer atrophy of pearl oyster

*: Significantly different from healthy oyster hemolymph - injected group (Fisher's exact test, $p<0.05)$. \#: Significantly different from healthy oyster hemolymph - injected group in the same experimental series (Steel - Dwass test, $p<0.05$ ). '; The number of oysters in which nacre abnormality was observed/the number of surviving oysters 
Table 5. Test 3: Filterability of causative agent of summer atrophy of pearl oyster

\begin{tabular}{|c|c|c|c|c|c|c|c|c|c|}
\hline & \multicolumn{4}{|c|}{$\begin{array}{l}\text { Pore size of membrane filters }(\mu \mathrm{m}) \text { used for } \\
\text { filtration of the hemolymph of affected oysters }\end{array}$} & \multicolumn{3}{|c|}{ Negative controls } & & \multirow{2}{*}{$\begin{array}{c}\text { Positive control } \\
\text { Cohabitation with } \\
\text { affected oysters }\end{array}$} \\
\hline & 0.8 & 0.45 & 0.22 & 0.1 & $\square$ & $\begin{array}{l}\text { Cohabitation } \\
\text { with healthy } \\
\text { oysters }\end{array}$ & $\begin{array}{c}\text { Injection with } \\
\text { healthy oyster } \\
\text { hemolymph }\end{array}$ & $\square$ & \\
\hline \multicolumn{10}{|l|}{ Experimental series-1 } \\
\hline Total number of deaths & 1 & 0 & 1 & 1 & & 0 & 0 & & 1 \\
\hline Nacre abnormalities! & $6 / 6^{*}$ & $7 / 7^{*}$ & $6 / 6^{*}$ & $5 / 6^{*}$ & & $0 / 7$ & $0 / 7$ & & $5 / 6^{*}$ \\
\hline Mean shell scores of survivors & $3.3 \pm 0.7^{\#}$ & $3.9 \pm 0.8^{\#}$ & $4.2 \pm 0.5^{\#}$ & $3.0 \pm 0.8^{\#}$ & & $0 \pm 0$ & $0 \pm 0$ & & $2.8 \pm 0.9^{\#}$ \\
\hline \multicolumn{10}{|l|}{ Experimental series-2 } \\
\hline Total number of deaths & 2 & 1 & 3 & 1 & & 0 & 0 & & 2 \\
\hline Nacre abnormalities! & $5 / 5^{*}$ & $6 / 6^{*}$ & $3 / 4^{*}$ & $6 / 6^{*}$ & & $2 / 7$ & $0 / 7$ & & $5 / 5^{*}$ \\
\hline Mean shell scores of survivors & $3.4 \pm 0.7^{\#}$ & $2.5 \pm 0.5^{\#}$ & $3.3 \pm 1.1^{\#}$ & $4.3 \pm 0.2^{\#}$ & $\square$ & $0.3 \pm 0.2$ & $0 \pm 0$ & $\square$ & $3.2 \pm 0.5^{\#}$ \\
\hline
\end{tabular}

*: Significantly different from healthy oyster hemolymph - injected group (Fisher's exact test, $\mathrm{p}<0.05$ ).

\#: Significantly different from healthy oyster hemolymph - injected group in the same experimental series (Steel - Dwass test, $p<0.05$ ).

!; The number of oysters in which nacre abnormality was observed/the number of surviving oysters 


\section{Table 6(on next page)}

Test 4: Mortality and disease appearances in serial passages

Blanks indicate that the experiments were not conducted. NM: not measured Passage 1 is common to all of the passage test series performed (i.e., every hour, 5 days, and 10 days) *: Significantly different from a negative control (Fisher's exact test, $p<0.05$ ) \#: Significantly different from a negative control (Steel-Dwass test, $p<0.05)$; The number of oysters in which nacre abnormality was observed/the number of surviving oysters 
Table 6. Test 4: Mortality and disease appearances in serial passages

\begin{tabular}{|c|c|c|c|c|c|c|}
\hline \multirow[b]{2}{*}{ No. of passages } & \multicolumn{3}{|c|}{ Negative control } & $\square$ & \multicolumn{2}{|c|}{ 1-hour passage series } \\
\hline & Dead/examined & Nacre abnormalities! & Mean shell scores of survivors & $\square$ Dead/examined & Nacre abnormalities! & Mean shell scores of survivors \\
\hline 1 & $0 / 7$ & $0 / 7$ & $0 \pm 0$ & $0 / 10$ & $10 / 10^{*}$ & $3.9 \pm 0.6^{\#}$ \\
\hline 2 & & & & $0 / 7$ & $6 / 7^{*}$ & $3.0 \pm 0.6$ \\
\hline \multirow[t]{2}{*}{3} & $\square$ & $\square$ & $\square$ & $0 / 7$ & $0 / 7$ & $0 \pm 0$ \\
\hline & \multicolumn{3}{|c|}{ 5-days passage series } & \multicolumn{3}{|c|}{ 10-days passage series } \\
\hline No. of passages & Dead/examined & Nacre abnormalities! & Mean shell scores of survivors & $\square$ Dead/examined & Nacre abnormalities! & Mean shell scores of survivors \\
\hline 1 & $0 / 10$ & $10 / 10^{*}$ & $3.9 \pm 0.6^{\#}$ & $0 / 10$ & $10 / 10^{*}$ & $3.9 \pm 0.6^{\#}$ \\
\hline 2 & $0 / 7$ & $7 / 7^{*}$ & $4.4 \pm 0.5^{\#}$ & $0 / 7$ & $7 / 7^{*}$ & $5.0 \pm 0.5^{\#}$ \\
\hline 3 & $0 / 7$ & $6 / 7^{*}$ & $3.1 \pm 0.8^{\#}$ & $3 / 7$ & $3 / 4^{*}$ & $1.8 \pm 0.6$ \\
\hline 4 & $0 / 7$ & $6 / 7^{*}$ & $3.3 \pm 0.7^{\#}$ & $0 / 7$ & $6 / 7^{*}$ & $1.9 \pm 0.6$ \\
\hline 5 & & & & $0 / 7$ & $6 / 7^{*}$ & $3.5 \pm 0.8^{\#}$ \\
\hline 6 & & & & NM & NM & NM \\
\hline 7 & & & & NM & NM & $\mathrm{NM}$ \\
\hline 8 & $\square$ & $\square$ & $\square$ & $1 / 7$ & $7 / 7^{*}$ & $4.0 \pm 0.9^{\#}$ \\
\hline
\end{tabular}

Blanks indicate that the experiments were not conducted. NM: not measured

Passage 1 is common to all of the passage test series performed (i.e., every hour, 5 days, and 10 days)

*: Significantly different from a negative control (Fisher's exact test, $\mathrm{p}<0.05$ )

\#: Significantly different from a negative control (Steel-Dwass test, $\mathrm{p}<0.05$ )

!; The number of oysters in which nacre abnormality was observed/the number of surviving oysters 


\section{Table 7 (on next page)}

Test 5: Sensitivity to chloroform of causative agent

*: Significantly different from the group injected with healthy pearl oyster hemolymph (Steel -

Dwass test, $p<0.05)$ '; The number of oysters in which nacre abnormality was observed/the number of surviving oysters 
Table 7. Test 5: Sensitivity to chloroform of causative agent

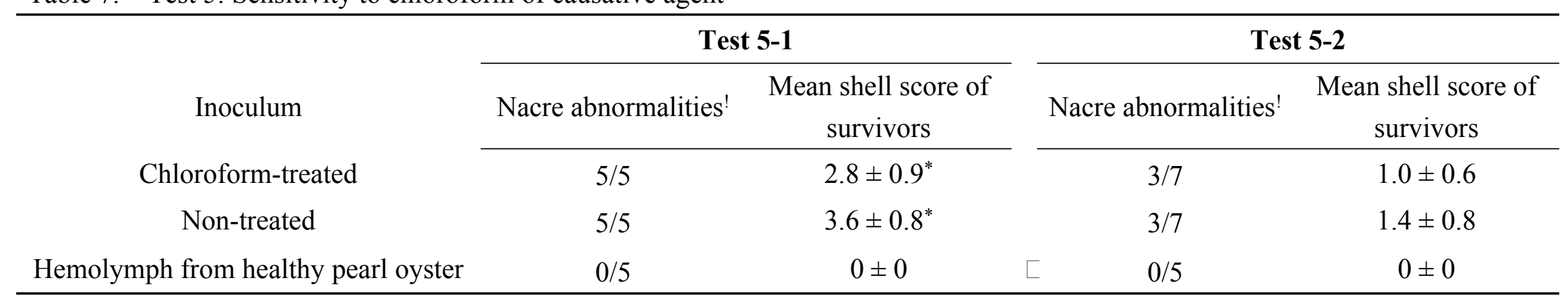

*: Significantly different from the group injected with healthy pearl oyster hemolymph (Steel - Dwass test, $p<0.05$ )

!; The number of oysters in which nacre abnormality was observed/the number of surviving oysters 


\section{Table 8(on next page)}

Test 6: Thermal stability of causative agent of suer atrophy of pearl oyster pathogenicity

*: Significantly different from healthy oyster hemolymph - injected group (Fisher's exact test, $p<0.05$ ). \#: Significantly different from healthy oyster hemolymph - injected group (Steel -

Dwass test, $p<0.05)$. '; The number of oysters in which nacre abnormality was observed/the number of surviving oysters 
Table 8. Test 6: Thermal stability of causative agent of summer atrophy of pearl oyster pathogenicity

\begin{tabular}{|c|c|c|c|c|c|c|}
\hline & \multicolumn{4}{|c|}{ Temperature } & \multicolumn{2}{|r|}{ Negative control } \\
\hline & on-ice & $40^{\circ} \mathrm{C}$ & $50^{\circ} \mathrm{C}$ & $60^{\circ} \mathrm{C}$ & $\square$ & $\begin{array}{l}\text { Injection with healthy } \\
\text { oyster hemolymph }\end{array}$ \\
\hline \multicolumn{7}{|l|}{ Test-1 } \\
\hline Nacre abnormalities! & $5 / 5^{*}$ & $4 / 5^{*}$ & $0 / 5$ & $0 / 5$ & & $0 / 5$ \\
\hline Mean shell scores of survivors & $2.0 \pm 0.4^{\#}$ & $2.0 \pm 0.6$ & $0 \pm 0$ & $0 \pm 0$ & & $0 \pm 0$ \\
\hline \multicolumn{7}{|l|}{ Test-2 } \\
\hline Nacre abnormalities! & $4 / 5^{*}$ & $3 / 5^{*}$ & $4 / 5^{*}$ & $0 / 5$ & & $0 / 5$ \\
\hline Mean shell scores of survivors & $2.8 \pm 0.9$ & $2.2 \pm 0.8$ & $2.4 \pm 0.8$ & $0 \pm 0$ & & $0 \pm 0$ \\
\hline
\end{tabular}

*: Significantly different from healthy oyster hemolymph - injected group (Fisher's exact test, $\mathrm{p}<0.05$ ).

\#: Significantly different from healthy oyster hemolymph - injected group (Steel - Dwass test, $\mathrm{p}<0.05$ ).

!; The number of oysters in which nacre abnormality was observed/the number of surviving oysters 